\title{
Comparative proteomic changes of differentially expressed whey proteins in clinical mastitis and healthy yak cows
}

\author{
X. Li ${ }^{1,2}$, X.Z. Ding ${ }^{2}$, Y.L. Wan ${ }^{3}$, Y.M. Liu' ${ }^{2}$ and G.Z. Du ${ }^{1}$ \\ ${ }^{1}$ The MOE Key Laboratory of Arid and Grassland Ecology School of Life Science, \\ Lanzhou University, Lanzhou, China \\ ${ }^{2}$ Institute of Lanzhou Animal Science and Veterinary Pharmaceutics, \\ Chinese Academy of Agricultural Sciences, Lanzhou, China \\ ${ }^{3}$ China Agricultural Veterinary Biology Science and Technology Company Limited, \\ Lanzhou, China \\ Corresponding author: X. Li \\ E-mail: lixia_lz@sohu.com
}

Genet. Mol. Res. 13 (3): 6593-6601 (2014)

Received January 24, 2013

Accepted September 3, 2013

Published August 28, 2014

DOI http://dx.doi.org/10.4238/2014.August.28.4

\begin{abstract}
Under the traditional grazing system on the QinghaiTibetan Plateau, the amount of milk in domesticated yak (Bos grunniens) with clinical mastitis decreases and the milk composition is altered. To understand the mechanisms of mammary gland secreted milk and disease infection, changes in the protein composition of milk during clinical mastitis were investigated using a proteomic approach. Milk whey from yak with clinical mastitis was compared to whey from healthy animals with two-dimensional gel electrophoresis using a mass spectrometer. Thirteen protein spots were identified to be four differentially expressed proteins. Increases in the concentrations of proteins of blood serum origin, including lactoferrin, were identified in mastitic whey compared to normal whey, while concentrations of the major whey proteins, casocidin-I, a-lactalbumin, and b-lactoglobulin, were downregulated in mastitic whey. These results indicated significant differences in protein
\end{abstract}


expression between healthy yaks and those with clinical mastitis, and they may provide valuable information for finding new regulation markers and potential protein targets for the treatment of mastitis.

Key words: Mastitis; Milk proteins; Two-dimensional gel electrophoresis

\section{INTRODUCTION}

The yak (Bos grunniens) is one of the world's most remarkable domestic animals that lives around the Himalayas at altitudes ranging from 3000 to $5500 \mathrm{~m}$ (Wiener et al., 2003). Approximately 15 million yaks, representing more than $90 \%$ of the world's total yak population, are raised on the Qinghai-Tibetan Plateau of China, and are the major source of livelihood for nomadic Tibetans in the highland plains (Ding et al., 2010). Previous studies have indicated that yak milk and its products have multifunctional and important effects for the health of Tibetans (Zhang et al., 2008) based on its nutritive value and biological and physico-chemical functions. Given the constraints of traditional milking and malnutrition when yaks are kept on seasonal grazing systems, the incidence of clinical and subclinical mastitis remains high in this extremely harsh environment (Xiao et al., 2008; Sun and Shen, 2009). Mastitis has considerable impacts for both the economy of the grazing industry and the quality of the local herders' livelihoods. Previous studies investigating the molecular mechanism that induces irreversible damage to mammary gland secreted milk, which results in permanent reduction in milk production, have identified the presence of acute phase proteins using a proteomic approach (Eckersall et al., 2001; Baeker et al., 2002; Talamo et al., 2003; Hogarth et al., 2004; D’Amato et al., 2009). Such explorations of protein expression patterns during clinical and subclinical mastitis milk changes could provide new diagnostic markers of mastitis, and have therefore prompted further investigation of the effect of this disease on the bovine milk proteome.

Analysis of milk proteins has major potential diagnostic significance because of the relative ease and adaptability of immunoassay methodologies and the ease of milk collection by noninvasive means. The identification and characterization of milk proteins is important for the development of new, clinically useful biomarkers and for studying the biochemistry and pathogenesis of different disease processes.

In the present investigation, expressed proteins in milk from clinical mastitic and healthy yaks were detected by two-dimensional gel electrophoresis (2-DE), thereby providing a platform for parallel analysis. Subsequently, differential protein expression was quantified with an ion trap mass spectrometer (MS) equipped with a high performance liquid chromatography (HPLC) system. Results of this analysis will shed light on the pathogenesis of mastitis and help to identify new biomarkers of mastitis-associated proteins for diagnosis and treatment.

\section{MATERIAL AND METHODS}

\section{Sample collection and preparation}

Fresh milk samples were collected from a small Tibetan farm in Tianzhu Tibetan Autonomous County on summer pasture $\left(36^{\circ} 35^{\prime} \mathrm{N}, 102^{\circ} 46^{\prime} \mathrm{E}\right)$, situated at the Qilian Mountain of the northeastern Qinghai-Tibetan Plateau. Clinical mastitis was identified on the basis of clini- 
cal signs (heat, pain, redness, and swelling of the udder, or clots in the milk). Whole milk was separated by centrifugation at $4000 \mathrm{~g}$ for $20 \mathrm{~min}$ at $4^{\circ} \mathrm{C}$, and the lipid-rich cream supernatant was discarded. The caseins were precipitated by the addition of saturated ice-cold $\left(\mathrm{NH}_{4}\right)_{2} \mathrm{SO}_{4}$ to the milk samples in an ice bath to a final concentration of $35 \% \mathrm{v} / \mathrm{v}\left(\mathrm{NH}_{4}\right)_{2} \mathrm{SO}_{4}$ (Hogarth et al., 2004). After centrifugation at $4000 \mathrm{~g}$ for $20 \mathrm{~min}$ at $4^{\circ} \mathrm{C}$, the supernatant (milk whey) was removed and dialyzed against deionized water at $4^{\circ} \mathrm{C}$ overnight. The protein concentration of the milk whey sample was assayed using the 2-D Quant Kit (Amersham Bioscience, Sweden) as a standard. The protein content of whey samples ranged from 2.5 to $10 \mathrm{mg} / \mathrm{mL}$.

\section{2-DE}

The first dimension electrophoresis was performed according to the method described by Hogarth et al. (2004) on a Bio-Rad PROTEAN isoelectric focusing (IEF) Cell at $20^{\circ} \mathrm{C}$. A whey sample containing $500 \mathrm{mg}$ total protein was diluted in rehydration buffer [ $8 \mathrm{M}$ urea; $4 \%$ w/v, CHAPS; $0.5 \% \mathrm{v} / \mathrm{v}$ ampholyte, and $65 \mathrm{mM}$ dithiothreitol (DTT)], applied by rehydration on separate nonlinear immobilized $\mathrm{pH}$ gradient (IPG) strips $(17 \mathrm{~cm}, \mathrm{pH} 3-10$, Bio-Rad) in a strip holder, focused in a Bio-Rad Protean IEF Cell at $20^{\circ} \mathrm{C}$ for $74750 \mathrm{Vh}$, and applied to a rampage program as previously described (Hogarth et al., 2004). After the IEF, IPG strips were removed carefully and equilibrated in sodium dodecyl sulfate (SDS) equilibration buffer (50 mM Tris-HCl, $\mathrm{pH} 8.8,6 \mathrm{M}$ urea, $30 \% \mathrm{v} / \mathrm{v}$ glycerol, $2 \% \mathrm{w} / \mathrm{v}$ SDS, $0.01 \% \mathrm{w} / \mathrm{v}$ bromophenol blue) containing $1 \% \mathrm{w} / \mathrm{v}$ DTT for $15 \mathrm{~min}$, followed by immersion in equilibrium buffer with $2.5 \% \mathrm{w} / \mathrm{v}$ iodoacetamide for an additional $15 \mathrm{~min}$. The IPG strips were then transferred onto $12 \%$ polyacrylamide gels, using $1.5 \mathrm{M}$ Tris- $\mathrm{HCl}, \mathrm{pH} 8.8$, as the separating gel buffer and Trisglycine-SDS, pH 8.3, as the electrode buffer, in a Bio-Rad Dodeca Cell. Gels were run at 200 $\mathrm{V}$ for $7 \mathrm{~h}$, stained with colloidal Coomassie blue $\mathrm{G}$ dye according to manufacturer instructions (Sigma-Aldrich, USA), and de-stained in $10 \% \mathrm{w} / \mathrm{v}$ acetic acid in $25 \% \mathrm{v} / \mathrm{v}$ methanol for $60 \mathrm{~s}$ followed by a further $24 \mathrm{~h}$ in $25 \% \mathrm{v} / \mathrm{v}$ methanol.

\section{Protein visualization and image analysis}

Protein spots were excised manually from the gels and visualized with silver staining as previously described (Mortz et al., 2001), while micro-preparative gels were stained with Coomassie blue. Stained gels were matched and detected using the PDQuest software (version 7.4, Bio-Rad, USA). Three independent samples were replicated for each pooled sample. Gel images were processed to remove backgrounds and to automatically detect protein spots. For comparisons of protein levels among gels, levels were normalized against the total intensity of all spots present in the gel.

\section{In-gel digestion}

Differentially expressed protein spots from whey were excised in approximately 1-3 $\mathrm{mm}^{2}$ pieces using a scalpel, rinsed in Millipore water, and de-stained with a solution containing $50 \%(\mathrm{v} / \mathrm{v})$ acetonitrile and $50 \mathrm{mM}$ ammonium bicarbonate $(\mathrm{pH} 7.8)$ three times (a total of $3 \mathrm{~h}$ ). The gel pieces were then dried under vacuum and rehydrated with modified trypsin (Promega, USA) in $50 \mathrm{mM}$ ammonium bicarbonate (pH 7.8). After $20 \mathrm{~min}, 20 \mu \mathrm{L} 50 \mathrm{mM}$ am- 
monium bicarbonate ( $\mathrm{pH} 7.8$ ) was added, and the mixture was incubated overnight at $37^{\circ} \mathrm{C}$ while being continuously shaken. The peptides were then extracted, first with $20 \mu \mathrm{L} 25 \mathrm{mM}$ ammonium bicarbonate ( $\mathrm{pH} 7.8$ ), then twice with $20 \mu \mathrm{L}$ solution containing $0.25 \%(\mathrm{v} / \mathrm{v})$ trifluoroacetic acid and 50\% (v/v) acetonitrile, and finally with 20-100 mL acetonitrile. The col-

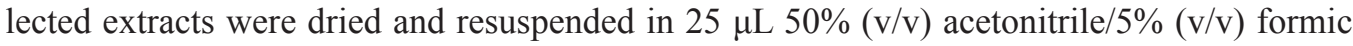
acid for liquid chromatography ion trap MS analysis.

\section{Protein identification and database search}

Peptide mass was determined using an ion trap mass spectrometer [4700 Proteomics Analyzer (TOF/TOFTM), Applied Biosystems, USA] equipped with a Surveyor HPLC System (Thermo, USA). Before injecting the peptide mixes, a $150 \times 0.18 \mathrm{~mm}$ BioBasic-18 column (Thermo) was equilibrated at a flow rate of $120 \mathrm{~mL} / \mathrm{min}$. Mobile phase A consisted of water and $0.1 \%$ formic acid, and mobile phase B consisted of acetonitrile and $0.1 \%$ formic acid. Peptides were eluted with a $0.1 \%$ formic acid/acetonitrile linear gradient over $120 \mathrm{~min}$. In the full scan mode, MS spectra for all samples were measured with an overall mass/charge $(\mathrm{m} / \mathrm{z})$ range of 400-2000, and MS/MS was performed in data-dependent mode. Peptides were identified using the SEQUEST software (Bioworks 2.0, Thermo Finnigan) to search against the publicly available NCBI non-redundant protein database (http://www.ncbi.nlm.nih.gov). The protein identification criteria were based on delta correlation scores (Delta CN; 0.1) and cross-correlation scores (Xcorr; one charge 1.9, two charges 2.2, three charges 3.75).

\section{RESULTS}

Milk whey proteins were resolved by 2-DE in the $\mathrm{pH}$ range of 3-10 in the first dimension, and the procedure was repeated three times under the same experimental conditions. The gel images were automatically matched and analyzed using the PDQuest 7.4 software to determine differentially expressed protein spots. The patterns of protein expression of normal whey and mastitic whey showed clear differences when separated using a broad range IEF strip ( $\mathrm{pH} 3-10$, nonlinear gradient). Over this $\mathrm{pH}$ gradient, a major group of protein spots was obtained with a streak ranging in isoelectric points (pI) from 4-8 and a molecular weight (Mr) range of 4500-80,000 $\mathrm{kDa}$ in both 2-DE colloidal Coomassie stained gels. Representative gels from the normal and clinically mastitic whey samples are shown in Figures 1A and 1B, respectively. Identifications of the numbered protein spots by matrix assisted laser desorption/ionization (MALDI)-MS revealed the major whey proteins as lactoferrin (LF; spots 6, 7, 8, 9, and 10), b-lactoglobulin (b-LG; spots 4 and 5), a-lactalbumin (a-LA; spots 2 and 3), caseins (spot 1), and albumin (spot 1) (Table 1). A representative tandem spectrum of a tryptic peptide obtained from spot 2 is shown in Figure 2. The double-charged peptide ions with an $\mathrm{m} / \mathrm{z}$ ratio signal were effectively fragmented to yield sufficient structural information for peptide identification.

In contrast, 2-DE performed on mastitic yak whey (Figure 1B) revealed an increased abundance of serum albumin and serotransferrin. Area 1 shows that the concentrations of the major whey proteins b-LG and a-LA were greatly reduced in mastitic whey. Normal bovine whey 2-DE profiles (Figure 1A) exhibited an abundance of casein proteins, including a-S1-casein, b-casein, and k-casein variants. However, although k-casein variants were 
evident in the mastitic whey, their levels were reduced in comparison to levels observed in normal whey. The 2-DE gel images showed the presence of several proteins as multiple spots (spots 1, 6, 7). The appearance of such strings of spots, with similar Mr but different pI values, is indicative of posttranslational modifications, such as glycosylation or different protein isoforms.
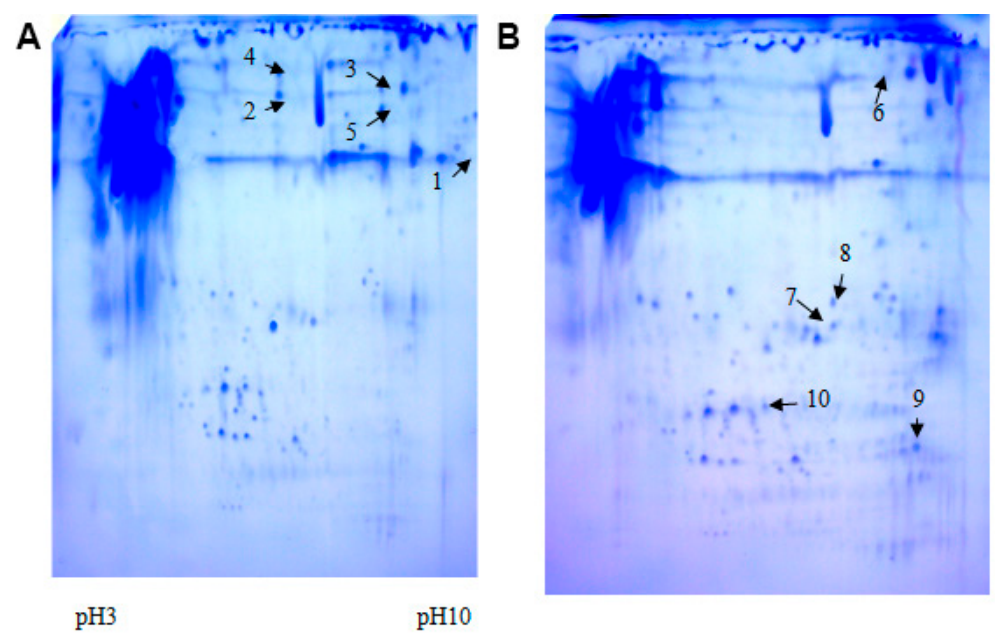

Figure 1 A. 2-DE colloidal Coomassie stained gel of normal bovine milk whey proteins separated using pH 4-7 IPG strips and $12 \%$ SDS-PAGE. The areas of interest are marked. Numbered spots were identified using MALDIMS and are listed in Table 1. B. 2-DE colloidal Coomassie stained gel of mastitic bovine milk whey proteins separated using pH 4-7 IPG strips and 12\% SDS-PAGE. The areas of interest are marked. Numbered spots were identified using MALDIMS and are listed in Table 1.

Table 1. Results of database searching for protein identification.

\begin{tabular}{|c|c|c|c|c|c|c|}
\hline Spot No. & Description & Mw & $\mathrm{pI}$ & Score & Accession No. & Sequence \\
\hline 1 & Casocidin- $\mathrm{I}=$ casein-alpha $\mathrm{s} 2$ derived & 4869.69 & 10.08 & 40.17 & 1176436 & $\begin{array}{l}\text {-.LTEEEKNR.- } \\
\text {-.LTEEEKNRLNFLK.- } \\
\text {-.FALPQYLK.- }\end{array}$ \\
\hline & antibacterial peptide & & & & & \\
\hline 2 & $\begin{array}{l}\text { Chain F, crystal structure of bovine } \\
\text { alpha-lactalbumin }\end{array}$ & 14186.06 & 4.80 & 90.19 & 12084477 & $\begin{array}{l}\text {-.DDQNPHSSNICNISCDK.- } \\
\text {-.VGINYWLAHK.- }\end{array}$ \\
\hline 3 & & & & 30.15 & & $\begin{array}{l}\text {-.LDQWLCEKL.- } \\
\text {-.ALCSEKLDQWLCEKL.- }\end{array}$ \\
\hline 4 & $\begin{array}{l}\text { Chain B, bovine beta-lactoglobulin, } \\
\text { lattice X }\end{array}$ & 18309.26 & 4.83 & 130.45 & 2194089 & $\begin{array}{l}\text {-.VLVLDTDYKK.- } \\
\text {-.VLVLDTDYK.- }\end{array}$ \\
\hline 5 & & & & 30.15 & & $\begin{array}{l}\text {-.TKIPAVFKIDALNENK.- } \\
\text {-.TPEVDDEALEKFDK.- }\end{array}$ \\
\hline 6 & $\begin{array}{l}\text { Structure of diferric bovine lactoferrin } \\
\text { at } 2.8 \text { angstroms resolution. }\end{array}$ & 76143.90 & 8.67 & 900.80 & 2781197 & $\begin{array}{l}\text {-.LRPVAAEIYGTK.- } \\
\text {-.RAFALECIR.- }\end{array}$ \\
\hline 7 & & & & 1224.54 & & $\begin{array}{l}\text {-.NCPDKFCLFKSETK.- } \\
\text {-.NGKNCPDKFCLFK.- }\end{array}$ \\
\hline 8 & & & & 458.59 & & $\begin{array}{l}\text {-.NCPDKFCLFK.- } \\
\text {-.NLLFNDNTECLAK.- }\end{array}$ \\
\hline 9 & & & & 1090.28 & & $\begin{array}{l}\text {-.LGGRPTYEEYLGTEYV } \\
\text { TAIANLKK.- }\end{array}$ \\
\hline 10 & & & & 400.52 & & -LGGRPTYEEYLGTEYVTAIANLK.- \\
\hline
\end{tabular}




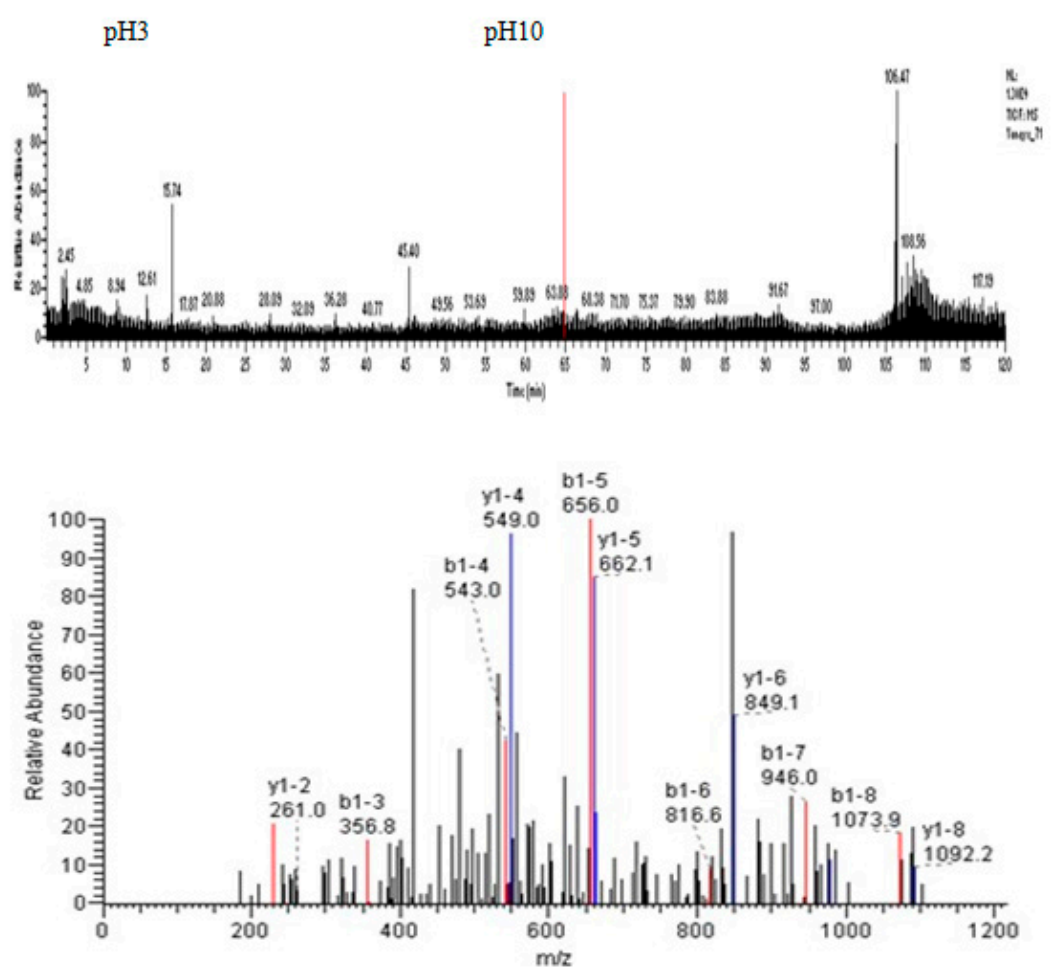

Figure 2. LC-MS/MS mass spectrum derived from Chain F, crystal structure of bovine alpha-lactalbumin.

\section{DISCUSSION}

Proteomics methods have been widely applied to study the pathophysiology of bovine mastitis and to identify novel, early, and sensitive biomarkers. Many studies have investigated proteome changes in mastitis milk (Hogarth et al., 2004; Smolenski et al., 2007; Boehmer et al., 2008; Danielsen et al., 2010) and plasma (Yang et al., 2009), with the aim of identifying diagnostic markers in easily accessible media. Other studies have focused on the composition of the milk fat globular membrane, which may be valuable for monitoring the pathological state of the mammary gland.

In total, only four proteins were identified (Figure 1, Table 1) in the present study, and the main whey proteins included casocidin-I (casein-alpha s2-derived antibacterial peptide), a-lactalbumin (Chain F, crystal structure of bovine alpha-lactalbumin), and b-lactoglobulin (Chain B, bovine beta-lactoglobulin lattice). It is well known that genetic polymorphisms and posttranslational modifications, such as glycosylation and phosphorylation, result in the formation of subtypes in milk proteins (Dovc, 2000; Ceciliani et al., 2007). The proteins identified in this study have already been described. b-LG is the most prevalent protein in bovine whey, comprising $10 \%$ of the total milk protein and approximately $58 \%$ of whey protein (Wong et al., 1996; Hogarth et al., 2004), and was here identified in 2-DE gels by LC-MS/MS as a series of spots with an $\mathrm{Mr}$ of $18.3 \mathrm{kDa}$ and a $\mathrm{pI}$ centered around 4.83. The biological func- 
tion of $\beta$-LG is currently unknown. However, the ligand binding properties that have emerged, coupled with the structural similarity of $\beta$-LG to retinol-binding proteins and possibly even to fatty acid-binding proteins, have led to the suggestion that it has a transport role for ligands such as retinol, fatty acids (Rocha et al., 1996; Brownlow et al., 1997), or vitamin A to neonates (Wong et al., 1997). a-LA is a calcium binding protein, accounting for approximately $13 \%$ of the total whey protein. It was here identified by LC-MS/MS in a series of protein spots with an $\mathrm{Mr}$ of $14.2 \mathrm{kDa}$ and a $\mathrm{pI}$ centered around 4.8. Under physiological conditions in the mammary gland, a-LA functions as a specifier protein, which modifies the substrate specificity of galactosyltransferase, and in complex with this enzyme, catalyzes the final step in the biosynthesis of lactose (Wong et al., 1997). The levels of both b-LG and a-LA detected here were very similar to the results obtained by Hogarth et al. (2004) in dairy cows. Furthermore, a-LA appeared as strings of spots, demonstrating that they are present as isoforms differing in charge, presumably as a result of posttranslational modifications, which are known to occur in these proteins prior to secretion.

Five unexpected spots $(6,7,8,9$, and 10) (Figure 1B) were identified as lactoferrin (LF) and were upregulated in mastitic whey, showing an $\mathrm{Mr}$ of $76.1 \mathrm{kDa}$ and a $\mathrm{pI}$ of 8.67 . LF is known to be an $80-\mathrm{kDa}$ iron-binding glycoprotein of the transferrin family, and has various biological and antimicrobial properties (Ward et al., 2002; Korhonen and Pihlanto, 2007) including roles in iron metabolism, cell proliferation and differentiation, and antibacterial, antiviral, and antiparasitic activity (Adlerova et al., 2008). A quite wide range of LF concentrations has been reported in healthy bovine milk, with values varying from $1.15 \mathrm{mg} / \mathrm{mL}$ (Hagiwara et al., 2003) to $485.63 \mathrm{mg} / \mathrm{mL}$. LF expression was shown to be significantly associated with the lactation stage $(r=0.557)$ and daily milk production $(r=-0.472)$ (Cheng et al., 2008). Its concentration was shown to increase substantially (up to $100 \mathrm{mg} / \mathrm{mL}$ ) during mammary gland involution (Welty et al., 1976). In the present study, LF may represent a positive acute-phase protein that is upregulated during inflammatory conditions such as diabetes.

Perhaps the most promising discovery in these proteomic analyses, however, was the identification of low-abundance proteins not previously reported in normal bovine milk (Yamada et al., 2002; Hogarth et al., 2004; Smolenski et al., 2007; Boehmer et al., 2008), which indicates the success of the current methods in identifying differentially expressed milk proteins during mastitis. Previous bioassays showed that the synthetic peptide casocidin-I exhibits an antibacterial effect (Zucht et al., 1995), and antimicrobial milk proteins, such as lactoferrin and its pepsin-derived peptide fragments (lactoferricins) and isracidin, were also described previously (Yamauchi et al., 1993; Lahov and Regelson, 1996). Casocidin-I was identified by LC-MS/MS in a series of protein spots with an $\mathrm{Mr}$ of $48.7 \mathrm{kDa}$ and a pI of approximately 10.08 (Table 1). Since human milk does not contain any casocidinI, these findings could explain the different influences of human and bovine milk on the gastrointestinal flora of the suckling.

Recent progress has been made, in both technical and biological aspects, toward identifying markers of experimentally induced mastitis by proteome analyses using the pathogens Staphylococcus aureus and Escherichia coli, which together account for more than $90 \%$ of all mastitis cases (Green et al., 2007). In the current study, 2-DE followed by MALDI-time of flight (TOF) MS is a powerful strategy for identification of the proteins that make up these maps, and constitutes a more straightforward approach than single protein determinations, which require specific assays for each protein. Furthermore, the peptide 
identity scores reported in the current study are robust and the protein identification criteria more stringent than those of single protein assays (Boehmer et al., 2008). Data collected in this work are of interest for contributing information about the physiological modifications of proteins that occur in different biological fluids, and associating corresponding variations with acute phase processes in farms. These results should aid in the construction of species- and disease-specific protein maps that will enable monitoring of the health status or the course of an infection under treatment, especially within the harsh environment of the Qinghai-Tibetan Plateau.

\section{ACKNOWLEDGMENTS}

Research supported by the National Natural Science Foundation of China (\#NSFC31101702). The authors would like to express their great appreciation to Prof. K.A. Johnson (Department of Animal Sciences, Washington State University) for revision of the manuscript.

\section{REFERENCES}

Adlerova L, Bartoskova A and Faldyna M (2008). Lactoferrin: a review. Vet. Med. 53: 457-468.

Baeker R, Haebel S, Schlatterer K and Schlatterer B (2002). Lipocalin-type prostaglandin D synthase in milk: a new biomarker for bovine mastitis. Prostag. Other Lipid Mediat. 67: 75-88.

Boehmer JL, Bannerman DD, Shefcheck K and Ward JL (2008). Proteomic analysis of differentially expressed proteins in bovine milk during experimentally induced Escherichia coli mastitis. J. Dairy Sci. 91: 4206-4218.

Brownlow S, Morais Cabral JH, Cooper R, Flower DR, et al. (1997). Bovine $\beta$-lactoglobulin at 1.8 A resolution - still an enigmatic lipocalin. Structure 5: 481-495.

Ceciliani F, Pocacqua V, Lecchi C, Fortin R, et al. (2007). Differential expression and secretion of alpha1-acid glycoprotein in bovine milk. J. Dairy Res. 74: 374-380.

Cheng JB, Wang JQ, Bu DP, Liu GL, et al. (2008). Factors affecting the lactoferrin concentration in bovine milk. J. Dairy Sci. 91: 970-976.

D’Amato A, Bachi A, Fasoli E, Boschetti E, et al. (2009). In-depth exploration of cow's whey proteome via combinatorial peptide ligand libraries. J. Proteome Res. 8: 3925-3936.

Danielsen M, Codrea MC, Ingvartsen KL, Friggens NC, et al. (2010). Quantitative milk proteomics - host responses to lipopolysaccharide-mediated inflammation of bovine mammary gland. Proteomics 10: 2240-2249.

Ding XZ, Long RJ, Kreuzer M, Mi JD, et al (2010). Methane emissions from yak (Bos grunniens) steers grazing or kept indoors and fed diets with varying forage: concentrate ratio during the cold season on the Qinghai-Tibetan Plateau. Anim. Feed Sci. Technol. 162: 91-98.

Dove P (2000). Genetic polymorphisms in milk protein genes and their impact on milk composition. Adv. Exp. Med. Biol. 480: 225-230.

Eckersall PD, Young FJ, McComb C, Hogarth CJ, et al. (2001). Acute phase proteins in serum and milk from dairy cows with clinical mastitis. Vet. Rec. 148: 35-41.

Green MJ, Leach KA, Breen JE, Green LE, et al. (2007). National intervention study of mastitis control in dairy herds in England and Wales. Vet. Rec. 160: 287-293.

Hagiwara S, Kawai K, Anri A and Nagahata H (2003). Lactoferrin concentrations in milk from normal and subclinical mastitic cows. J. Vet. Med. Sci. 65: 319-323.

Hogarth CJ, Fitzpatrick JL, Nolan AM, Young FJ, et al. (2004). Differential protein composition of bovine whey: a comparison of whey from healthy animals and from those with clinical mastitis. Proteomics 4: 2094-2100.

Korhonen H and Pihlanto A (2007). Technological options for the production of health-promoting proteins and peptides derived from milk and colostrum. Curr. Pharmaceut. Des. 13: 829-843.

Lahov E and Regelson W (1996). Antibacterial and immunostimulating casein-derived substances from milk: casecidin, isracidin peptides. Food Chem. Toxicol. 34: 131-145.

Mortz E, Krogh TN, Vorum H and Gorg A (2001). Improved silver staining protocols for high sensitivity protein 
identification using matrix-assisted laser desorption/ionization-time of flight analysis. Proteomics 1: 1359-1363.

Rocha TL, Brownlow S, Saddler KN, Fothergill-Gilmore LA, et al. (1996). New crystal form of $\beta$-lactoglobulin. J. Dairy Res. 63: 575-584.

Smolenski G, Haines S, Kwan FY, Bond J, et al. (2007). Characterisation of host defence proteins in milk using a proteomic approach. J. Proteome Res. 6: 207-215.

Sun XF and Shen YY (2009). The epidemiological research of subclinical mastitis in yak. Chin. Qinghai J. Anim. Vet. Sci. 2: 10-11.

Talamo F, D'Ambrosio C, Arena S, Del Vecchio P, et al. (2003). Proteins from bovine tissues and biological fluids: defining a reference electrophoresis map for liver, kidney, muscle, plasma and red blood cells. Proteomics 3: 440-460.

Ward PP, Uribe-Luna S and Conneely OM (2002). Lactoferrin and host defense. Biochem. Cell Biol. 80: 95-102.

Welty FK, Smith KL and Schanbacher FL (1976). Lactoferrin concentration during involution of the bovine mammary gland. J. Dairy Sci. 59: 224-231.

Wiener G, Han JL and Long RJ (2003). The Yak. 2nd edn. Regional Office for Asia and the Pacific. Food and Agriculture Organization (FAO) of the United Nations, Bangkok.

Wong CW, Seow HF, Husband AJ, Regester GO, et al. (1997). Effects of purified bovine whey factors on cellular immune functions in ruminants. Vet. Immunol. Immunopathol. 56: 85-96.

Wong DW, Camirand WM and Pavlath AE (1996). Structures and functionalities of milk proteins. Crit. Rev. Food Sci. Nutr. 36: 807-844.

Xiao HY, Hao BQ, Gao W and Qin TY (2008). Study on bovine mastitis pathogens of yak milk with isolation and identification. J. Southwest Univ. Nationalities Nat. Sci. Edition 5: 955-959.

Yamada M, Murakami K, Wallingford JC and Yuki Y (2002). Identification of low-abundance proteins of bovine colostral and mature milk using two-dimensional electrophoresis followed by microsequencing and mass spectrometry. Electrophoresis 23: 1153-1160.

Yamauchi K, Tomita M, Giehl TJ and Ellison RT, III (1993). Antibacterial activity of lactoferrin and a pepsin-derived lactoferrin peptide fragment. Infect. Immun. 61: 719-728.

Yang YX, Zhao XX and Zhang Y (2009). Proteomic analysis of mammary tissues from healthy cows and clinical mastitic cows for identification of disease-related proteins. Vet. Res. Commun. 33: 295-303.

Zhang HP, Xu J, Wang JG, Menghebilige, et al. (2008). A survey on chemical and microbiological composition of kurut, naturally fermented yak milk from Qinghai in China. Food Control 19: 578-586.

Zucht HD, Raida M, Adermann K, Mägert HJ, et al. (1995). Casocidin-I: a casein-as2 derived peptide exhibits antibacterial activity. FEBS Lett. 372: 185-188. 